\title{
EFFECT OF GROWTH REGULATORS AND OTHER COMPONENTS OF CULTURE MEDIUM ON MORPHOGENESIS OF SUGAR BEET (Beta vulgaris L.) IN UNFERTILISED OVULE IN VITRO CULTURES
}

\author{
Magdalena Tomaszewska-Sowa \\ Department of Plant Physiology and Fundamentals of Biotechnology \\ University of Technology and Life Sciences in Bydgoszcz, Bernardyńska 6, 85-029 Bydgoszcz, Poland \\ e-mail:magda@utp.edu.pl
}

Received: 14.06 .2012

\begin{abstract}
The aim of the present research was to optimise the process of plant regeneration from unfertilised ovules in sugar beet (Beta vulgaris L.). A two-stage method was applied which involved preculture in liquid MS medium and culture on solid media. The study evaluated the effectiveness of different groups of growth regulators, agar and gelrite on the morphogenesis of explants. To do so, the culture was maintained on $21 \mathrm{MS}$ media containing auxins (NAA, IBA, 2,4-D), cytokinins (BAP, KIN, TDZ), antiauxin (TIBA) as well as solidifying substances at different concentrations and combinations. Varied effectiveness of callus and shoot formation was observed depending on the medium used. The highest efficiency of shoot formation was recorded on the media containing 4.4 $\mu \mathrm{M}$ BAP, $0.09 \mathrm{M}$ sucrose, and $0.04 \%$ gelrite. The formation of roots was induced when exposed to $14.8 \mu \mathrm{M}$ IBA and $0.049 \mu \mathrm{M} 2 \mathrm{iP}$, and the percentage of rooted shoots ranged from 0.0 to $65.2 \%$, depending on the growth regulator combination used for shoot regeneration.
\end{abstract}

Keywords: sugar beet, in vitro cultures, regeneration, gynogenesis, ovules, growth regulators

List of abbreviations: BAP - 6-benzylaminopurine, IBA - indole-3-butyric acid, KIN - 6-furfurylaminopurine, MS - Murashige and Skoog (1962) medium, NAA - 1-naphthaleneacetic acid, TDZ - thidiazuron, TIBA - 2,3,5 triiodobenzoic acid, 2iP - 6- , (dimethyl allylamino)purine, 2,4-D - 2,4-dichlorophenoxyacetic acid.

\section{INTRODUCTION}

In the last dozen or so years, in vitro techniques have become an essential element of programmes aiming at creating new valuable initial material for breeding as well as for the improvement of sugar beet cultivars. Benefiting from the achievements of research studies, they have facilitated a fast progress in the reproduction of valuable genotypes and in the production of homozygotic lines and genetically modified lines (G ürel et al. 2000; K u y ke ndall et al. 2003; $\mathrm{Me}$ ze i et al. 2006). One of the methods of obtaining haploids and double haploids of beet is culture of unfertilised ovules and diploidization of plantlets regenerated from the cells of the embryo sac. The first reports on gynogenesis come from 1983 and 1985 when $0.23 \%$ and $0.17 \%$ of plants of gametic chromosome number were obtained from the ovules of male sterile and fertile plants (Hosemans and B os s outrot, 1983; B o s s outrot and Ho se mans, 1985).

Further experiments on beet in vitro cultures aimed mostly at increasing the number of differentiating explants, the share of haploids in the regenerates as well as the development of efficient methods of doubling the number of chromosomes (Gośka, 1997; Han se n et al. 1998; Hansen et al. 2000). The researchers described a few new effective methods of plant regeneration from tissue and cell explants, while the existing procedures were optimised and also adapted to specific genotypes defined by the breeders. A considerable enhancement in the effectiveness of those processes was recorded, e.g., as a result of media composition modification, the selection of the most adequate development stages of ovules, and adapting the physical conditions of in vitro culture, mostly temperature and photoperiod (Doctrinal et al. 1989; Ferrant and Bouharmont, 1994; Gośka, 1997). 
Despite a clear progress in producing haploids and double haploids, the results of the earlier reports are not always satisfactory as far as the effectiveness of haploidization is concerned. Therefore, the research covered by this paper aimed at testing a number of factors which could affect the pattern of regeneration processes. The procedures described so far have been improved, e.g. thanks to the application of preculture of ovules in liquid media. Such preculture could be maintained for at least 12 months, which made the initiation of specific culture possible in any season of the year, and thus an increase in the number of regenerates formed and making the organogenesis induction process independent of the dates of isolation of ovules from flower buds during the flowering of the plant. The working hypothesis assumed that the application of innovative two-stage ovule culture, during which the effect of a few growth regulators and solidifying substances would be compared, would allow the separation of such combinations that would enhance the processes of organogenesis and shoot formation.

\section{MATERIALS AND METHODS}

The research material consisted of sugar beet (Beta vulgaris L.) plants, produced as a result of in vitro reproduction of a single diploid mother plant, genotype 0170, obtained from the Kutno Sugar Beet Breeding Station (Plant Breeding Station at Straszkowo) (Fig. 1A). $5 \mathrm{~cm}$ segments of generative shoots were surface sterilized using 70\% ethanol (1 min.) and 5\% calcium hypochlorite with two drops of Tween 20 (20 min.). After receiving the disinfection treatments, the shoot segments were rinsed three times with sterile distilled water. The ovules were isolated under sterile conditions from 3-4 closed flower buds located on a sterile generative shoot (Fig. 1B). Isolated ovules were cultured in liquid Murashige and Skoog medium (MS) (1962) containing $4.4 \mathrm{mM}$ 6-benzylaminopurine (BAP)

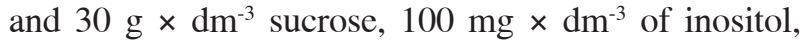
$0.4 \mathrm{mg} \times \mathrm{dm}^{-3}$ of thiamine with a pH of 5.8. The explants were inoculated into a $100-\mathrm{ml}$ Erlenmeyer flask containing $25 \mathrm{ml}$ of liquid medium and were cultured on a rotary shaker $(150 \mathrm{rpm})$. After 12 weeks of culture in liquid medium, the regenerating structures (Fig. 2) were transferred onto MS media of varied composition (Table 1). The modifications involved the application of various combinations of auxins: indole-3-butyric acid (IBA), 1-naphthaleneacetic acid (NAA), 2,4-dichlorophenoxyacetic acid (2,4-D) and cytokinins: 6-furfurylaminopurine (KIN), thidiazuron (TDZ), BAP as well as antiauxin: 2,3,5 triiodobenzoic acid (TIBA) and two solidifying substances: agar (Becton Dickinson and Company, USA) at the concentration of 0.2, 0.4, and $0.7 \%$ as well as gelrite at the concentration of $0.4 \%$.
The control (medium No. 1) consisted of MS medium without growth regulators (Table 1). MS regeneration media with a $\mathrm{pH}$ of 5.8 were used and during culture on regeneration media the explants were transferred onto fresh media every 4 weeks. The development of 60 regenerating structures ( 3 reps, 20 explants each in a $100-\mathrm{ml}$ Erlenmeyer flask), exposed to a temperature of $24^{\circ} \mathrm{C}$ and 16 -hour photoperiod, at the light intensity of about $40 \mathrm{mmol} \times \mathrm{m}^{-2} \times \mathrm{s}^{-1}$, was analysed in each experimental treatment. At the successive stage of the experiment, two-times subculturing onto the same media was performed.

To start the induction of rhizogenesis, the shoots were transferred onto MS medium supplemented with: $14.8 \mu \mathrm{M}$ IBA and $0.049 \mu \mathrm{M}$ 6- - -(dimethyl allylamino)purine (2iP). After 8 weeks of culture, the rooted shoots were cleaned from agar and planted into a mixture of gardening soil and perlite and placed in a greenhouse under a plastic tunnel to reduce transpiration. At the beginning of the growing season, after 6 to 8 weeks of acclimatization, the plants were planted out into experimental plots of the Institute of Plant Breeding and Acclimatization in Bydgoszcz. After the growing period, the storage roots were dug out and placed in a storage place of the Plant Breeding Station at Straszkowo at the temperature of $4^{\circ} \mathrm{C}$ to be planted into soil in the following spring and to isolate fragments of generative shoots at flowering and, under sterile conditions, to isolate ovules from the fragments.

The experiment investigated the following parameters:

- number of explants forming shoots or callus (after 4 weeks of culture on solid media);

- shoot formation effectiveness on the respective media (after 12 weeks of culture on solid media);

- rooting effectiveness (after 8 weeks on rooting medium).

The applicability of respective types of media for the induction of beet regeneration processes was evaluated based on the number of shoots and plants produced. The results were compared with the corresponding data for the control medium. The statistical analysis was made using the R-Spearman rank test which was primarily designed to compare the media in terms of their effectiveness on the process of shoot formation and root formation.

\section{RESULTS}

\section{Regeneration}

Morphogenetic observations were made of about 4500 unfertilised ovules isolated over the pe- 
riod 2004-2007. In a two-stage culture during the liquid phase, $3.8 \%$ of the ovules found on the medium were identified with structures green in colour, which suggested the beginning of differentiating processes (Fig. 3A). Regenerating structures were separated from the other ones, reproduced and kept in liquid culture (Fig. 3B). From the tissues obtained in liquid cultures, 1260 differentiating structures (Fig. 4A, B) were sampled and transferred onto 21 solid MS media of varied composition (Table 1).

The evaluation of the morphogenetic potential of the tissues obtained in ovules cultures made after four weeks of the development on regenerating media showed that of all the differentiating structures, $36 \%$ started the development by forming shoots or callus tissue, while the other ones got darker and withered (Fig. 5A). The process of organogenesis was observed for $63 \%$ of regenerating explants, while the other $37 \%$ formed callus (Fig. 5B, C).

Ovule differentiation gave the best effects for BAP content in the medium at the concentration of $4.4 \mu \mathrm{M}$, especially with the addition of gelrite $(60 \%)$, compared with the MS medium control where the processes of differentiation were observed in 19 cases (32\%) (Table 2), while a weaker reaction was recorded for the lower concentrations of BAP addition, either as the only regulator or combined with NAA. Of all the media that contained BAP and agar as the solidifying substance, most shoots (71) regenerated when exposed to its lowest concentration, namely $0.44 \mu \mathrm{M}$. As for BAP at the concentration of $2.2 \mu \mathrm{M}$, adding NAA increased the number of shoots as compared with the amount recorded on the medium without auxin (Table 2).

On the media containing KIN in the combination with NAA or 2,4-D, most explants forming shoots were observed in the presence of $2.2 \mu \mathrm{M}$ KIN and $0.44 \mu \mathrm{M}$ NAA $(32 \%)$. The capacity for shoot formation was insignificant on the media with $0.44 \mu \mathrm{M}$ KIN supplemented with $0.44 \mu \mathrm{M}$ NAA $(15.0 \%)$ or in $0.44 \mu \mathrm{M} 2,4-\mathrm{D}(13.3 \%)$, due to the fact that on those media callus was formed at a considerable amount $(18.3 \%, 61.7 \%)$ (Table 2).

In another treatment - MS media with TIBA, only $7(1 \mu \mathrm{M}$ TIBA) and 6 plants $(2 \mu \mathrm{M}$ TIBA) were produced, while in the presence of TDZ a different number of shoots was obtained: from $13(1 \mu \mathrm{M}$ TDZ) to 26 (5 $\mu \mathrm{M}$ TDZ) (Table 2).

The most intensive regeneration was observed on the medium supplemented with $4.4 \mu \mathrm{M}$ BAP, $0.09 \mathrm{M}$ sucrose and $0.4 \%$ gelrite. On that medium, $60 \%$ of the explants formed 73 shoots with numerous leaves with adequately developed, intensely green laminas. Factoring in the effect of the other solidifying substances on organogenesis effectiveness, $0.7 \%$ agar was reported to create better conditions for differentia- tion at further culture stages than its lower concentrations, producing as many as 71 shoots (Table 2).

\section{Shoot rooting and plant acclimatization}

To perform the induction of rhizogenesis, the shoots were transferred from regenerating media onto the MS medium enriched with $14.8 \mu \mathrm{M}$ IBA and $0.049 \mu \mathrm{M} 2 \mathrm{iP}$. After about eight weeks, out of the total of 584 regenerates 211 (36\%) formed roots (Table 3). Relatively good results were recorded for the shoots developing on the media with BAP or KIN supplemented with $0.44 \mu \mathrm{M}$ NAA. The percentage of rooted microcuttings, as compared with the total number of regenerates, was highest when they were derived from the medium containing $2.2 \mu \mathrm{M}$ KIN and $0.44 \mu \mathrm{M}$ NAA. Of the total of 23 shoots, 15 took root, which accounts for $65.2 \%$. A high percentage of rooted shoots was also reported when $1 \mu \mathrm{M}$ TIBA $(57.1 \%)$ as well as $5 \mu \mathrm{M}$ TDZ and $1 \mu \mathrm{M}$ IBA $(53.8 \%)$ were added to the regeneration media (Table 3).

The rooted shoots (Fig. 6A) were acclimatized in the glasshouse (Fig. 6B). Of the total of 211 plants planted out into pots, $80 \%$ were acclimatized to ex vitro conditions.

\section{Statistical analysis}

The statistical analysis of the present results obtained with the $\mathrm{R}$ - Spearman ranking correlation method presents a relationship between the ranking of the medium described by the average number of shoots produced from a single explant (X) and the ranking of that medium described by the number of rooted shoots (Y). Based on the results of ranking assignment, one can conclude that the media on which a high number of shoots per explant was produced also enhanced plant rooting effectiveness; this can be seen from the fact that those media, representing quartiles I and II, account for $50 \%$ of the value in the order series. Out of a total of 21 analysed media which differed in the type and concentration of growth regulators, solidifying substances or other compounds which are to intensify the processes of shoot regeneration, media no. 2, 6, 5, 7, 8, 9, 10, 21 were the best in terms of both characters, according to the statistical non-parametrical R-Spearman's ranking correlation method (Table 4). The accompanying high capacity of both processes points to the highest effectiveness of those media in the process of ovule regeneration in in vitro cultures. The lowest efficiency, for the characters evaluated at the same time, is found for the media located in quartile IV $(3,4,11,13,14$, $18,17,19,20)$; this position demonstrates their limited applicability in producing regenerated and rooted plants from explants derived from in vitro ovules (Table 4). This analysis is confirmed by the results obtained by calculating shoots and rooted plants. 
Table 1

Murashige and Skoog (MS) medium modifications applied in the experiment

\begin{tabular}{|c|c|c|c|c|}
\hline \multirow{2}{*}{ Medium number } & \multicolumn{4}{|c|}{ Concentration and type of medium components used } \\
\hline & Cytokinins & Auxins & Solidifying substance & Other \\
\hline 1 & - & - & $0.7 \%$ agar & - \\
\hline 2 & $4.4 \mu \mathrm{M}$ BAP & - & $0.7 \%$ agar & - \\
\hline 3 & $4.4 \mu \mathrm{M}$ BAP & - & $0.4 \%$ agar & - \\
\hline 4 & $4.4 \mu \mathrm{M}$ BAP & - & $0.2 \%$ agar & - \\
\hline 5 & $4.4 \mu \mathrm{M}$ BAP & - & $0.4 \%$ gerlit & - \\
\hline 6 & $0.44 \mu \mathrm{M}$ BAP & - & $0.7 \%$ agar & - \\
\hline 7 & $2.2 \mu \mathrm{M}$ BAP & - & $0.7 \%$ agar & - \\
\hline 8 & $0.44 \mu \mathrm{M}$ BAP & $0.44 \mu \mathrm{M}$ NAA & $0.7 \%$ agar & - \\
\hline 9 & $2.2 \mu \mathrm{M}$ BAP & $0.44 \mu \mathrm{M}$ NAA & $0.7 \%$ agar & - \\
\hline 10 & $4.4 \mu \mathrm{M}$ BAP & $0.44 \mu \mathrm{M}$ NAA & $0.7 \%$ agar & - \\
\hline 11 & $0.44 \mu \mathrm{M}$ KIN & $0.44 \mu \mathrm{M}$ NAA & $0.7 \%$ agar & - \\
\hline 12 & $2.2 \mu \mathrm{M}$ KIN & $0.44 \mu \mathrm{M}$ NAA & $0.7 \%$ agar & - \\
\hline 13 & $4.4 \mu \mathrm{M}$ KIN & $0.44 \mu \mathrm{M}$ NAA & $0.7 \%$ agar & - \\
\hline 14 & $0.44 \mu \mathrm{M}$ KIN & $0.44 \mu \mathrm{M} 2,4-\mathrm{D}$ & $0.7 \%$ agar & - \\
\hline 15 & $2.2 \mu \mathrm{M}$ KIN & $0.44 \mu \mathrm{M} 2,4-\mathrm{D}$ & $0.7 \%$ agar & - \\
\hline 16 & $4.4 \mu \mathrm{M}$ KIN & $0.44 \mu \mathrm{M} 2,4-\mathrm{D}$ & $0.7 \%$ agar & - \\
\hline 17 & $4.4 \mu \mathrm{M}$ BAP & - & $0.7 \%$ agar & $1.0 \mu \mathrm{M}$ TIBA \\
\hline 18 & $4.4 \mu \mathrm{M}$ BAP & - & $0.7 \%$ agar & $2.0 \mu \mathrm{M}$ TIBA \\
\hline 19 & $1.0 \mu \mathrm{M}$ TDZ & $1.0 \mu \mathrm{M}$ IBA & $0.7 \%$ agar & - \\
\hline 20 & $3.0 \mu \mathrm{M}$ TDZ & $1.0 \mu \mathrm{M}$ IBA & $0.7 \%$ agar & - \\
\hline 21 & $5.0 \mu \mathrm{M}$ TDZ & $1.0 \mu \mathrm{M}$ IBA & $0.7 \%$ agar & - \\
\hline
\end{tabular}

Table 2

Efficiency of shoot and callus formation in Beta vulgaris L. depending on the regeneration medium composition (* numbers 1 to 21 correspond to the numbers of media as given in Table 1)

\begin{tabular}{|c|c|c|c|c|}
\hline Medium number* & Regenerating structures (\%) & Explants forming shoots (\%) & Explants forming callus (\%) & Final shoot number \\
\hline 1 & 31.7 & 28.3 & 3.3 & 30 \\
\hline 2 & 41.7 & 32.0 & 10.0 & 51 \\
\hline 3 & 50.0 & 42.0 & 8.3 & 21 \\
\hline 4 & 33.3 & 20.0 & 13.3 & 19 \\
\hline 5 & 60.0 & 60.0 & 0.0 & 73 \\
\hline 6 & 30.0 & 27.0 & 3.3 & 71 \\
\hline 7 & 11.7 & 10.0 & 1.6 & 40 \\
\hline 8 & 13.3 & 13.3 & 0.0 & 24 \\
\hline 9 & 23.3 & 20.0 & 3.3 & 53 \\
\hline 10 & 15.0 & 15.0 & 0.0 & 46 \\
\hline 11 & 33.3 & 15.0 & 18.3 & 3 \\
\hline 12 & 38.3 & 32.0 & 6.7 & 23 \\
\hline 13 & 30.0 & 23.0 & 6.7 & 9 \\
\hline 14 & 75.0 & 13.3 & 61.7 & 8 \\
\hline 15 & 90.0 & 28.3 & 61.7 & 21 \\
\hline 16 & 83.3 & 16.7 & 66.7 & 17 \\
\hline 17 & 16.7 & 10.0 & 6.6 & 7 \\
\hline 18 & 10.0 & 10.0 & 0.0 & 6 \\
\hline 19 & 20.0 & 11.7 & 8.3 & 13 \\
\hline 20 & 30.0 & 30.0 & 0.0 & 23 \\
\hline 21 & 16.7 & 16.7 & 0.0 & 26 \\
\hline
\end{tabular}


Table 3

Effectiveness of rhizogenesis in Beta vulgaris L. depending on the regeneration medium composition (*numbers 1 to 21 correspond to the numbers of media as given in Table 1)

\begin{tabular}{cccc}
\hline Medium number* & Number of shoots & Number of rooted shoots & Rooted shoots $(\%)$ \\
\hline 1 & 30 & 6 & 20.0 \\
2 & 51 & 13 & 26.0 \\
3 & 21 & 12 & 57.0 \\
4 & 19 & 0 & 0.0 \\
5 & 73 & 39 & 53.0 \\
6 & 71 & 21 & 29.6 \\
7 & 40 & 12 & 30.0 \\
8 & 24 & 10 & 42.0 \\
9 & 53 & 23 & 43.4 \\
10 & 46 & 17 & 37.0 \\
11 & 3 & 1 & 33.3 \\
12 & 23 & 15 & 65.2 \\
13 & 9 & 4 & 44.4 \\
14 & 8 & 3 & 37.5 \\
15 & 21 & 4 & 19.0 \\
16 & 17 & 5 & 29.4 \\
17 & 7 & 4 & 57.1 \\
18 & 6 & 2 & 33.3 \\
19 & 13 & 3 & 23.0 \\
20 & 23 & 3 & 13.0 \\
21 & 26 & 14 & 53.8 \\
\hline
\end{tabular}

Table 4

Ordering of the number of regenerated shoots and rooted shoots of Beta vulgaris L. in series considering the simultaneous presence in the respective quartiles (*numbers 1 to 21 correspond to the numbers of media as given in Table 1)

\begin{tabular}{|c|c|c|c|c|c|}
\hline \multirow{2}{*}{$\begin{array}{l}\text { Representing } \\
\text { the same quartile }\end{array}$} & \multirow{2}{*}{$\begin{array}{l}\text { Medium } \\
\text { number* }\end{array}$} & \multirow{2}{*}{$\begin{array}{l}\text { Mean number of } \\
\text { shoots per explant }\end{array}$} & \multirow{2}{*}{$\begin{array}{l}\text { Number of rooted } \\
\text { shoots }\end{array}$} & \multicolumn{2}{|c|}{ Mean for each quartile } \\
\hline & & & & Number of shoots & Number of rooted shoots \\
\hline \multirow{3}{*}{ Quartile I } & 6 & 4.44 & 21 & \multirow{3}{*}{4.6} & \multirow{3}{*}{20.3} \\
\hline & 9 & 4.42 & 23 & & \\
\hline & 10 & 5.11 & 17 & & \\
\hline \multirow{5}{*}{ Quartile II } & 2 & 2.68 & 13 & \multirow{5}{*}{3.39} & \multirow{5}{*}{17.6} \\
\hline & 5 & 2.03 & 39 & & \\
\hline & 7 & 6.67 & 12 & & \\
\hline & 8 & 3.00 & 10 & & \\
\hline & 21 & 2.60 & 14 & & \\
\hline \multirow{4}{*}{ Quartile III } & 1 & 1.75 & 6 & \multirow{4}{*}{1.48} & \multirow{4}{*}{7.5} \\
\hline & 12 & 1.21 & 15 & & \\
\hline & 15 & 1.24 & 4 & & \\
\hline & 16 & 1.70 & 5 & & \\
\hline \multirow{9}{*}{ Quartile IV } & 3 & 0.84 & 12 & \multirow{9}{*}{1.08} & \multirow{9}{*}{3.5} \\
\hline & 4 & 1.58 & 0 & & \\
\hline & 11 & 0.33 & 1 & & \\
\hline & 13 & 0.64 & 4 & & \\
\hline & 14 & 1.00 & 3 & & \\
\hline & 17 & 1.17 & 4 & & \\
\hline & 18 & 1.00 & 2 & & \\
\hline & 19 & 1.86 & 3 & & \\
\hline & 20 & 1.28 & 3 & & \\
\hline
\end{tabular}



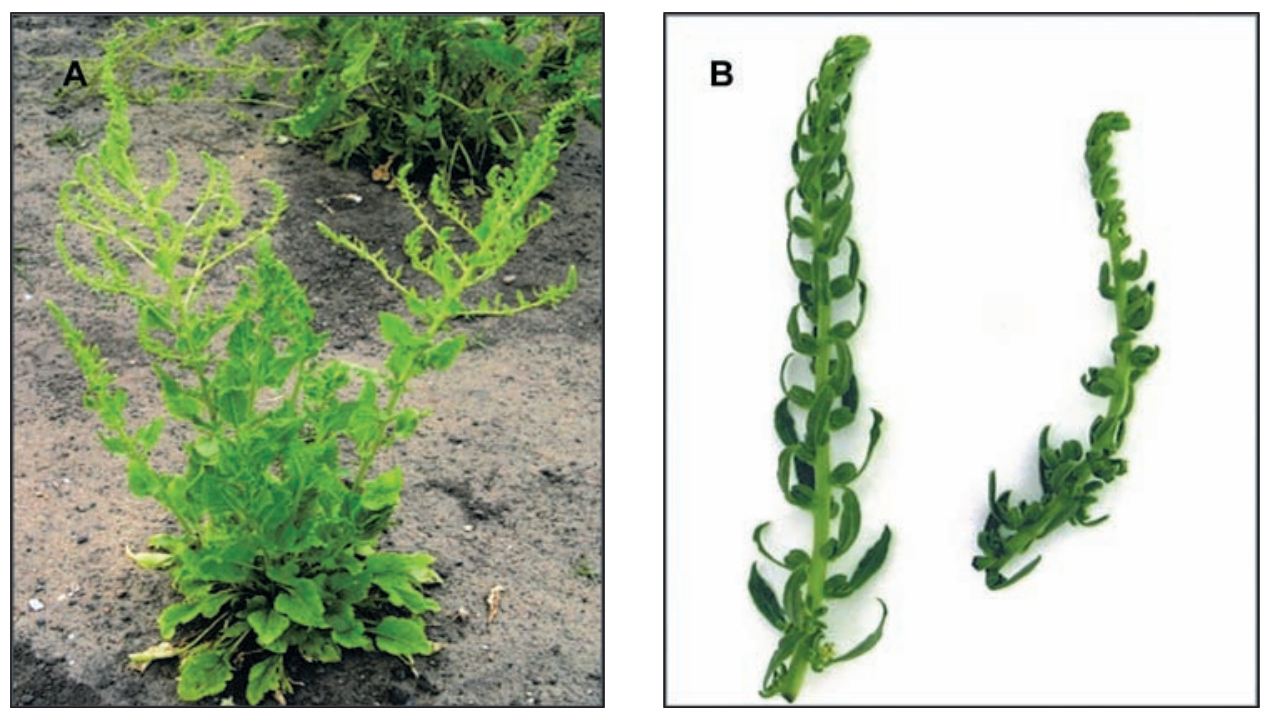

Fig. 1. Flowering Beta vulgaris L. mother plant, genotype 0170 (A), cut-off generative shoot fragments (B).

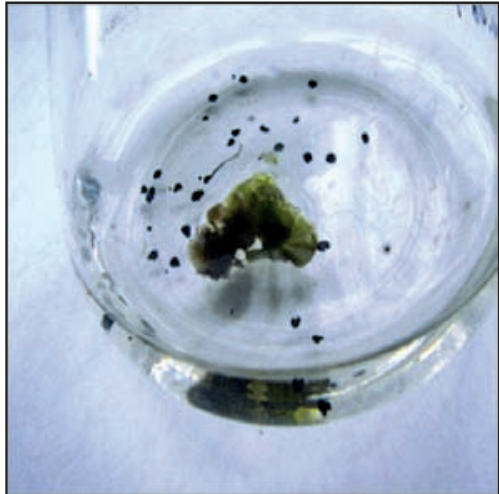

Fig. 2. Differentiating ovules of Beta vulgaris L. in liquid media after 12 weeks of culture.
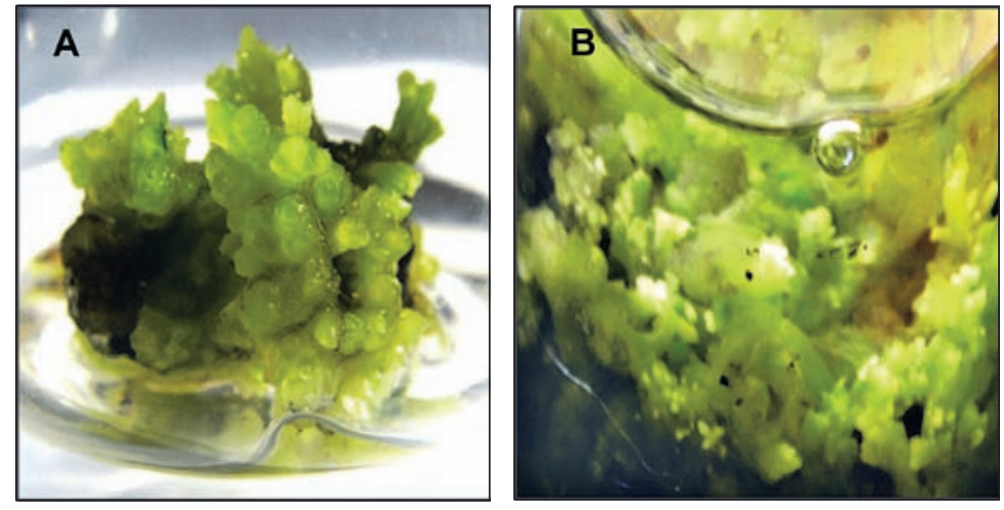

Fig. 3. Regenerating ovules of Beta vulgaris L. in the initial culture in liquid media: after 14 (A) and after 20 weeks (B).
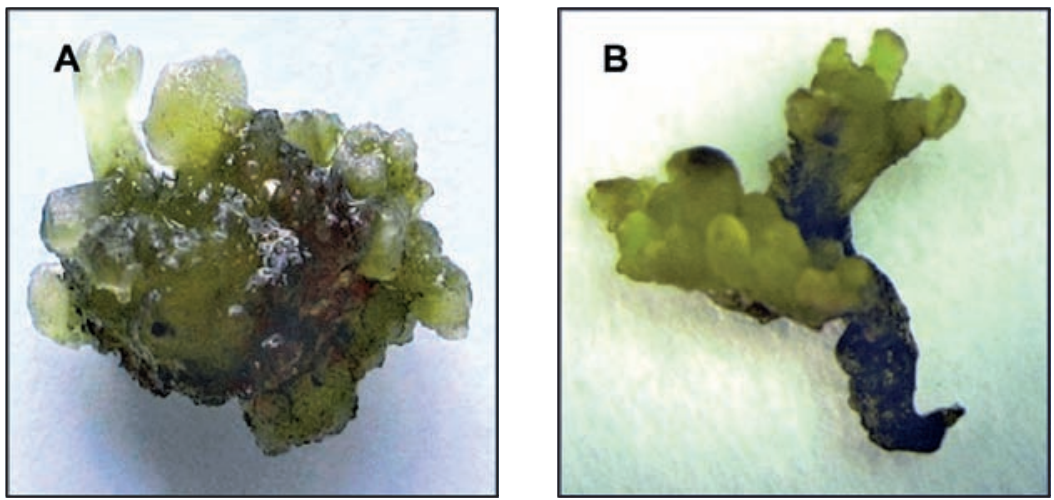

Fig. 4. Regenerating structures of Beta vulgaris L. transferred onto solid MS media (A, B). 

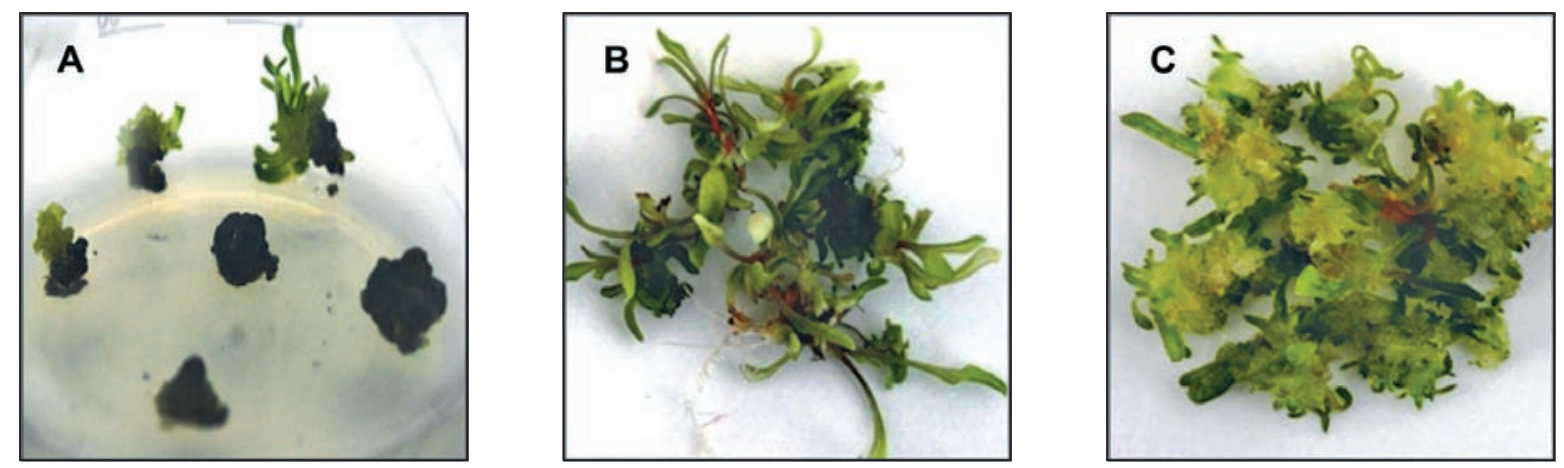

Fig. 5. Stages of Beta vulgaris L. regeneration on solid media: initiation of callus and shoot anlages, visible withering explants (A), isolated shoots used for successive passages (B), and organogenic callus tissue (C).
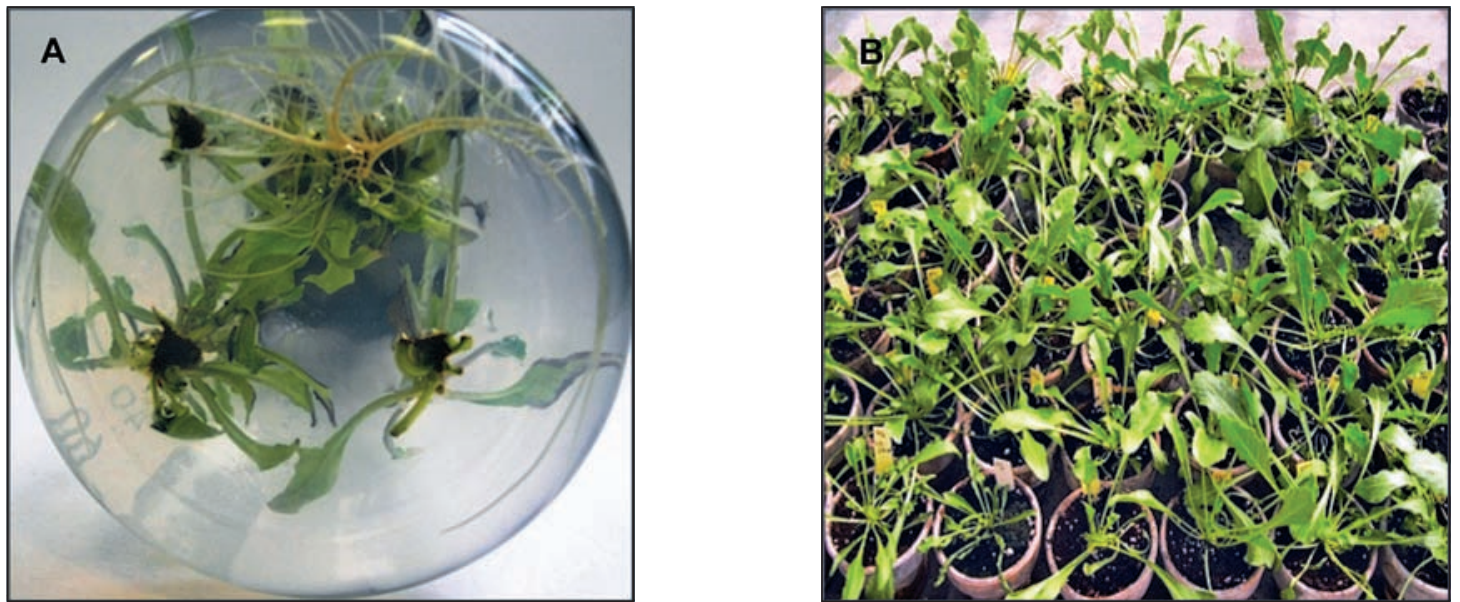

Fig. 6. Rooted in vitro Beta vulgaris L. shoots (A), plants after 8 weeks of acclimatization in the glasshouse (B).

\section{DISCUSSION}

The present paper describes the effect of phytohormones and other components of culture medium on morphogenesis of sugar beet in unfertilised ovule in vitro cultures. The unfertilized ovules were taken in June and July from flower buds located right under the bud being at the phase of anthesis. The reports by Gośk a (1997) confirmed that ovules in such flowers contain a functional fully-developed embryo sac, and the most optimal date for isolation of explants is the period from May through September, which was documented by Doctrinal et al. (1989) as well as by $\mathrm{L} \mathrm{u} \mathrm{x}$ et al. (1990). The potential capacity of ovules for differentiation is closely correlated with the genotype, which is seen from the results reported by B o s s outrot and Hosemans (1985), Gośka (1997), Hosemans and B os soutrot (1983), Lux et al. (1990), Van Geyt et al. (1987), and Yu (1992). These authors recorded a considerable variation in regeneration effectiveness, especially in haploid plants, within the lines studied since they recorded a varied number of differentiating ovules or they did not observe any symptoms of regeneration at all.
The experiment involved a two-stage culture: at the first stage, differentiation was observed on liquid medium and then on solid media of varied composition. The method offers a few advantages, e.g. it ensures obtaining much more material than in the case of culture of ovules incubated throughout the culture on solid medium. Additionally, differentiating tissues can be successively taken up and transferred onto regenerating media, which eliminates one of the serious limitations in ovule cultures, namely the need to obtain material only during a short plant flowering stage. With that in mind, the method offers greater effectiveness of plant regeneration than the procedures described by other authors (D' Halluin and Ke imer, 1986; Doctrinal et al., 1990; Lux et al. 1990). In the present protocol, differentiating structures from liquid media were transferred onto solid MS media. As indicated in numerous reports, the medium developed by Murashige and Skoog (1962) turned out to be the medium on which the highest regeneration efficiency was recorded (G ośka, 1997; L u x et al. 1990; V a n G e y t et al. 1987), although the literature offers reports on gynogenesis induction involving 
also other media, such as: vitamins-rich medium B5 (Gamborg et al. 1968), SH (S chenk and Hildeb randt, 1972), $\mathrm{PG}_{0 \mathrm{~B}}$ (D' H a llu in and Ke i mer, 1986), and N6 (D o c trin a 1 et al. 1990), or the media developed by $\mathrm{Zhu}$ and $\mathrm{Wu}$ (1979) as well as $\mathrm{R} \mathrm{a}$ qu in (1982) applied so far in cultures of ovules in wheat and petunia thecae (B os s outrot and $\mathrm{Ho}$ s e m a n s, 1985).

Of all the phytohormones tested in this experiment, the best effects in ovule differentiation and shoot regeneration were obtained in the case of BAP. The results from successive passages show that BAP had a stimulating effect on pedogenesis, as compared with the control. A slightly different reaction was observed throughout the propagation of the initiated shoots. The shoots obtained in the presence of this cytokinin demonstrated normal habit, saturated green colour, and an adequate growth. Numerous leaf laminas were narrow and without discolorations. To perform further research into the effect of growth regulators on plant development, from the group of cytokinins BAP was replaced with KIN. In the present experiment, KIN in combination with NAA, irrespective of the concentration applied, demonstrated lower organogenesis induction effectiveness than the BAP-containing media. The number of regenerates produced was lower than in the control and the plants showed glassy deformed leaves with elongated thin laminas. During the regeneration process, we could observe hormonal control of the morphogenetic potential of plants. Variation in the capacity to regenerate from ovules depending on auxins and cytokinins introduced into the medium and their concentration was also reported by Gośk a (1997). Of all the genotypes investigated, the best results were reported by this author for the medium containing 0.3 or $1.0 \mathrm{mg} \times \mathrm{dm}^{-3} \mathrm{BAP}$ in combination with $0.1 \mathrm{mg}$ $\times \mathrm{dm}^{-3}$ NAA. Considering those results, it is demonstrated that the effectiveness of gynogenesis depended on the ratio of cytokinins to auxins in the medium, which also coincided with the reports by $\mathrm{V}$ a n $\mathrm{Ge}$ y $\mathrm{t}$ et al. (1987) who applied BAP, NAA and 2,4-D and recorded an about $50 \%$ decrease in the number of regenerated plants when exposed to high doses of cytokinin, as compared to those of auxins. Other authors have found that with no cytokinins, the processes of differentiation and regeneration can be inhibited (D o c trinal et al. 1989).

A considerably lower, than the control, morphogenetic potential was observed on TIBA-containing media. Supplementing the TIBA medium limited the organogenesis frequency. Shoots were growing slowly, while the leaf laminas were narrow and often deformed. However, there are sources pointing to other types of beet explants reacting better to the TIBA content in the medium. This relationship, in combi- nation with BAP, intensifies organogenesis in cultures of callus derived from various explants $(\mathrm{T}$ e $\mathrm{tu}$ et al. 1987). The observations coincide with the reports by Dovzhenko and Koop (2003) documenting a positive effect of antiauxin on the organogenesis of the protoplasts isolated from the embryogenic callus. The induction properties of TIBA were also reported by $\mathrm{W}$ iśniew ska (2006) who compared the regeneration of shoots from stomatal protoplasts in beet on 14 regenerating media, including media containing antiauxin. The highest efficiency of that process (53 shoots) was noted by the author in the presence of 4.0 $\mu \mathrm{M}$ TIBA.

The application of TDZ and IBA did not have a significant effect on an increase in ovule regeneration effectiveness, as compared with the control, despite the fact that the positive effect of TDZ on the effectiveness of morphogenesis in other beet explant types, for instance laminas and leaf petioles as well as explants from seedling fragments, was reported by e.g. Zh ang et al. (2001) and Gośk a (2004). These results suggest that the use of higher concentrations of those phytohormones resulted in a increase of the number of shoots. The regenerated shoots, however, showed poor growth, deformed, frequently vitrified leaves, and numerous necrotic changes.

Considering the effect of agar and gelrite, as solidifying substances, on morphogenesis in beet, the better results was observed for gelrite and $0.7 \%$ agar. A decrease in agar content in the medium resulted in a slow-down of the plant growth rate, leaf deformation and increased susceptibility to vitrification. All that coincides with the results reported by other authors who claim that $0.7-0.8 \%$ agar is applied in the standard procedure in ovule cultures in beet $(\mathrm{Gośka}$ and $\mathrm{J}$ a s s e m, 1988; Gü rel et al. 2000). The occurrence of explant vitrification is triggered not only by a low concentration of the solidifying substance but also high air humidity and insufficient reduced nitrogen content in the medium (J o y c e et al. 2003). Plant material vitrification can be seen from anatomic and physiological changes considerably decreasing the morphogenetic potential of explants; by some authors, this is accounted for by disturbed polyamine metabolism, which can result in triggering defence reactions seen as, e.g., high activity of peroxidases and poor cell wall lignification (Piqueras et al. 2002). According to Fontes et al. (1999), vitrification in Capsicum annuиm plants is connected with the synthesis of proteins of thermal shock, the expression of which occurs under stress.

The in vitro regenerated shoots were transferred from the regenerating media onto the MS medium supplemented with IBA and 2iP. The effectiveness of such regulator composition in the rooting medium is confirmed by the analysis reported by Gośk a (1997). 
The results of the experiments show that the effectiveness of root induction clearly depended on the composition of shoot-regeneration medium. One of the essential factors affecting root formation is the type and concentration of the solidifying substance present in the regeneration medium. The use of $0.4 \%$ agar or $0.4 \%$ gelrite, instead of the standard $0.7 \%$ agar, resulted in an over two-fold increase in the process effectiveness, which could have been due to the agar composition, mostly in the presence of harmful compounds which can have a negative effect on plants by limiting cell proliferation and elongation (S t e f a n i a k, 2004).

The plants were transferred to pots and acclimatized under controlled conditions. In the initial period of acclimatization, the plants were intensively watered and kept under a plastic tunnel, which increased the efficiency of the process.

\section{CONCLUSIONS}

1. The paper describes the method of unfertilised ovule stimulation for differentiation; it involved a two-stage culture allowing unlimited reproduction of initiation tissues in liquid medium from which, at any time of the year, one can trigger the induction of organogenesis processes.

2. It was shown that the effectiveness of shoot formation depended on the composition of regeneration medium. As regards the number of shoots, the medium with $4.4 \mu \mathrm{M}$ BAP supplemented with $0.09 \mathrm{M}$ sucrose and solidified with $0.4 \%$ gelrite in which a more than double number of shoots was produced, as compared with the control medium, showed to be the best.

3. The results of the experiments demonstrate that the effectiveness of the rooting process depended on the type and concentration of the phytohormone present in the medium. The highest percentage of rooted microcuttings, as compared with the total number of regenerates, was reported when they originated from the medium containing $2.2 \mu \mathrm{M}$ KIN and $0.44 \mu \mathrm{M}$ NAA. However, another important factor affecting root formation was the type and concentration of the solidifying substance present in the regeneration medium. The application of $0.4 \%$ agar or $0.4 \%$ gelrite resulted in a more than double increase in the process effectiveness.

4. At the final stage of the experiment, a high value (over $80 \%$ ) of the coefficient of acclimatization of plants to ex vitro conditions was recorded.

\section{Acknowledgements}

I wish to express my kind thanks to Professor Anna Majewska-Sawka, VitroGen, Bydgoszcz, for providing her precious advice for developing this publication and to Professor Ewa Jędrzejczak of the Department of Botany and Ecology, University of Technology and Life Sciences in Bydgoszcz, for her assistance with analysing statistical results.

\section{REFERENCES}

Bossoutrot D., Hosemans D. 1985. Gynogenesis in Beta vulgaris L.: from in vitro culture of unpollinated ovules to the production of doubled haploid plants in soil. Plant Cell Rep. 4: 300-303. http://dx.doi.org /10.1007\%2FBF00269883

D'Halluin K., Keimer B. 1986. Production of haploid sugar beets (Beta vulgaris L.) by ovule culture. [In:] Genetic Manipulation in Plant Breeding, W. Horn, C.J. Jerser, W. Odenbach, O.Schieder, (eds). Walter de Gruyter Berlin, New York. 307-309.

Doctrinal M., Sangwan R.S., Sangwan-Norre el B.S. 1989. In vitro gynogenesis in Beta vulgaris L.: Effects of plant growth regulators, temperature, genotypes and season. Plant Cell Tiss. Org. Cult. 17: 1-12. http://dx.doi.org/10.1007\%2F978-3-642-61499-6_17

Doctrinal M., Sangwan R.S, S angwan-Norreel B.S. 1990. Sugarbeet (Beta vulgaris L.): In vitro induction of haploids. Biotechnol. Agric. For. Haploids in Crop Improvement, 12: 346-357.

Dovzhenko A., Koop H.U. 2003. Sugarbeet (Beta vulgaris L.): shoot regeneration from callus and protoplasts. Planta, 217: 374-381. http://dx.doi.org/10.1007\% 2Fs00425-003-1006-7

Ferrant V., Bouharmont J. 1994. Origin of gynogenetic embryos of Beta vulgaris L. Sexual Plant Rep. 7: 12-16.

Fontes M.A., Otoni W.C., Carolino S.M.B., Brommonschenkel S.H., Fontes E.P.B., Fari M, Luoro R.P. 1999. Hyperhydricity in pepper plants regeneration in vitro: involvement of $\mathrm{BiP}$ (Binding Protein) and ultrastructural aspects. Plant Cell Rep. 19: 81-87. http://dx.doi.org/10.1007\%2Fs002990050714

Gamborg O.L., Miller R.A., Ojiwa K. 1968. Nutrient requirements of suspension culture of soybean root callus. Exp. Cell Res. 50: 151-158.

Gośka M. 1997. Haploidy i podwojone haploidy buraka cukrowego (Beta vulgaris L.) oraz możliwości ich wykorzystania w hodowli. / Haploids and doubled haploids of sugar beet (Beta vulgaris L.) and their use in breeding. Monografie i rozprawy naukowe. IHAR, 2: 1-81. (in Polish)

Gośka M. 2004. Wpływ cytokinin na morfogenezę buraka cukrowego (Beta vulgaris L.) w kulturach in vitro. / Effect of cytokinins on morphogenesis of sugar beet (Beta vulgaris L.) in in vitro cultures. Biotechnologia, 2 (65): 137-145. (in Polish)

Gośka M., Jas s e m B. 1988. Histological observations of sugar-beet ovules in in vitro cultures. Bull. Pol. Acad. Sci. Biol. Sci. 36: 171-175. 
Gürel S., Gürel E., Kaya Z. 2000. Doubled haploid plant production from unpollinated ovules of sugar beet (Beta vulgaris L.). Plant Cell Rep. 19: 1155-1159.

Hansen A., Gertz A., Joersbo M., Andersen S.B. 1998. Antimicrotubule herbicides for in vitro chromosome doubling in Beta vulgaris L. ovule culture. Euphytica, 101: 231-237.

Hansen A.L., Gertz A., Joersbo M., Andersen S.B. 2000. Chromosome doubling in vitro with amiprophos methyl in Beta vulgaris ovule culture. Acta Agric. Scand. 50: 89-95.

Hosemans D., B os soutrot D. 1983. Induction of haploid plants from in vitro culture of unpollinated beet ovules (Beta vulgaris L.). Z. Pflanzenzchtg. 91: 74-77.

Joyce S., Casse11s A.C., Jain S.M.2003. Stress and aberrant phenotypes in in vitro culture. Plant Cell, Tiss. Org. Cult. 74: 103-121.

Kuykendall L.D., Saunders J.W., Stockett T.M. 2003. Rhizobium radiobacter conjugation and callus independent shoot regeneration used to introduce the cercosporin export gene $c f p$ from cercospora into sugar beet (Beta vulgaris L.). Biotechnol. Lett. 25: 739-744.

Lux H., Herrmann L., Wetzel C. 1990. Production of haploid sugar beet (Beta vulgaris L.) by culturing unpollinated ovules. Plant Breed. 104: 177-183. http:// dx.doi.org/10.1111\%2Fj.1439-0523.1990.tb00420.x

Mezei S., Kovacev L., Nagl N. 2006. Sugar beet micropropagation. Biotechnol. \& Biotechnol. Eq. 20: 9-14.

Murashige T., Skoog F. 1962. A revised medium for rapid growth and bioassay with tobacco tissue cultures. Physiol. Plant. 15: 473-497.

Piqueras A., Cortina M., Serna M.D., Casas J.L. 2002. Polyamines and hyperhydricity in micropropagated carnation plants. Plant Sci. 162: 671-678. http://dx. doi.org/10.1016\%2FS0168-9452\%2802\%2900007-9

Raquin C. 1982. Analyse des s gr gations de g nes impliqu $\mathrm{s}$ dans la pigmentation florale des $\mathrm{p}$ tunias issus d'androgen se / Analysis of genes segregation involved in floral pigmentation in petunias from androgenesis. C. R. Acad. Sc. Paris, 294: 335-338.

Schenk R.U., Hildebrandt A.C. 1972. Medium and techniques for the induction and growth of monocotyledonous and dicotyledonous plant cell cultures. Can. J. Bot. 50: 199-204. http://dx.doi.org/10.1139\%2Fb72-026

S tefa niak B. 2004. Roślinne kultury in vitro. Komórki roślinne w warunkach stresu. / Plant in vitro cultures. Plant cells under stress conditions. In: A. Woźny, K. Przybyło (eds.). UAM Poznań, Poland: 14-91. (in Polish)

Tetu T., Sangwan R.S., Sangwan-Norreel B.S. 1987. Hormonal control of organogenesis and somatic embryogenesis in Beta vulgaris callus. J. Exp. Bot. 38: 506-517.
Van Geyt J, Spockmann Jr. G.J., Halluin K.D., J a c obs M. 1987. In vitro induction of haploid plants from unpollinated ovules and ovaries of the sugarbeet (Beta vulgaris L.). Theor. Appl. Genet. 73: 920-925.

Wiśn iewska E. 2006. Charakterystyka cytologiczna i genetyczna komórek o wysokim i niskim potencjale do regeneracji roślin in vitro (Nicotiana tabacum L. Vs Beta vulgaris L.). / Cytological and genetic characteristics of cells with high and low potential for in vitro regeneration of plants (Nicotiana tabacum L. Vs. Beta vulgaris L.). IHAR. PhD Thesis, 1-149. (in Polish)

$\mathrm{Yu}$ M.H. 1992. Growth and reproduction performance of ovule-induced sugarbeet plants. Sabrao J. 24: 47-55.

Zhang C.L., Chen D.F., Elliot M.C., Slater A. 2001. Thidiazuron-induced organogenesis and somatic embryogenesis in sugar beet (Beta vulgaris L.). In Vitro Cell. Dev. Biol. Plant. 37: 305-310. http://dx.doi.org/ 10.1007\%2Fs11627-001-0054-6

Z hu Z.C., W u H. 1979. In vitro induction of haploid plants from the unpollinated ovaries of Triticum aestivum and Nicotiana tabacum. Acta Genet. Sin. 6: 181-183.

\section{Wpływ regulatorów wzrostu i innych składników pożywki na morfogenezę buraka cukrowego (Beta vulgaris $\mathbf{L}$.) w kulturach in vitro niezapłodnionych zalążków}

\section{Streszczenie}

Celem przeprowadzonych badań była optymalizacja procesu regeneracji roślin $\mathrm{z}$ niezapłodnionych zalążków buraka cukrowego (Beta vulgaris L.). Zastosowano metodę dwufazową obejmującą prekulturę w płynnej pożywce MS i kulturę na pożywkach stałych. Oceniono skuteczność oddziaływania różnych grup regulatorów wzrostu oraz agaru i gerlitu na morfogenezę eksplantatów. W tym celu kulturę prowadzono na 21 pożywkach MS zawierających auksyny (NAA, IBA, 2,4-D), cytokininy (BAP, KIN, TDZ), antyauksynę (TIBA) a także substancje zestalające $\mathrm{w}$ różnych stężeniach i kombinacjach. Zaobserwowano zróżnicowaną efektywność formowania kalusa i pędów w zależności od zastosowanego podłoża. Najwyższą wydajność formowania pędów uzyskano na pożywkach zawierających 4,4 $\mu \mathrm{M}$ BAP, 0,09 M sacharozy i 0,04\% gerlitu. Formowanie korzeni indukowano w obecności $14,8 \mu \mathrm{M}$ IBA i $0,049 \mu \mathrm{M}$ 2iP, a udział ukorzenionych pędów wahał się od 0,0 do $65,2 \%$, w zależności od wariantu doświadczenia. 